\title{
The History and Horizons of Microscale Neural Interfaces
}

\author{
Takashi D. Y. Kozai 1,2,3,4,5 \\ 1 Department of Bioengineering, University of Pittsburgh, Pittsburgh, PA 15261, USA; tdk18@pitt.edu \\ Center for the Neural Basis of Cognition, University of Pittsburgh, Pittsburgh, PA 15213, USA \\ Center for Neuroscience, University of Pittsburgh, Pittsburgh, PA 15261, USA \\ McGowan Institute of Regenerative Medicine, University of Pittsburgh, Pittsburgh, PA 15212, USA \\ NeuroTech Center, University of Pittsburgh Brain Institute, Pittsburgh, PA 15260, USA
}

Received: 7 August 2018; Accepted: 3 September 2018; Published: 6 September 2018

check for updates

\begin{abstract}
Microscale neural technologies interface with the nervous system to record and stimulate brain tissue with high spatial and temporal resolution. These devices are being developed to understand the mechanisms that govern brain function, plasticity and cognitive learning, treat neurological diseases, or monitor and restore functions over the lifetime of the patient. Despite decades of use in basic research over days to months, and the growing prevalence of neuromodulation therapies, in many cases the lack of knowledge regarding the fundamental mechanisms driving activation has dramatically limited our ability to interpret data or fine-tune design parameters to improve long-term performance. While advances in materials, microfabrication techniques, packaging, and understanding of the nervous system has enabled tremendous innovation in the field of neural engineering, many challenges and opportunities remain at the frontiers of the neural interface in terms of both neurobiology and engineering. In this short-communication, we explore critical needs in the neural engineering field to overcome these challenges. Disentangling the complexities involved in the chronic neural interface problem requires simultaneous proficiency in multiple scientific and engineering disciplines. The critical component of advancing neural interface knowledge is to prepare the next wave of investigators who have simultaneous multi-disciplinary proficiencies with a diverse set of perspectives necessary to solve the chronic neural interface challenge.
\end{abstract}

Keywords: micromachine; neuroscience; biocompatibility; training; education; diversity; bias; BRAIN Initiative; multi-disciplinary; micro-electromechanical systems (MEMS)

\section{Introduction}

Neurotechnologies that are capable of stimulating or recording from a small population of neurons have revolutionized quality of life by enabling the deaf to hear [1,2], the blind to see [3,4], and the paralyzed to write, grasp, and walk [5-11]. The advancement of this technology has seen a dramatic growth over the past decade which has attracted additional attention and increasing promises of what these devices can accomplish to further improve quality of life. These neurotechnologies can range from implants that are inserted deep within the nervous system to non-invasive wearable technologies that generally have more limited capabilities. Key progress feeding into the growth of this field is the investment from major pharmaceutical and start-up companies to provide alternatives to drugs with side-effects as well as increased congressional and government support in developing and maintaining the infrastructural apparatus for technology development. In parallel, advancements in batteries, wireless recharging, miniaturization, sensors, computer chips, and advancements in decoding algorithms and machine learning promise potential for dramatic advances in the coming decades. 
These neural interface technologies were originally employed as tools for basic science research in order to study how the brain works [12-15]. Basic science mapping experiments were carried out by using neural interfaces to electrically stimulate various regions of the brain or the nervous system and observing muscle twitches [16-20]. Mapping was also carried out in the opposite direction by applying sensory stimulation or driving motor activity and recording ionic currents from action potentials using microscale neural recording interfaces [21-23]. From these experiments, academic researchers discovered that specific functions of the nervous system were encoded in specific regions of the brain and nerve bundles [24-29]. Furthermore, they discovered that the frequency of action potentials recorded generally corresponded to the intensity of activity (sensation or muscle activation) [13-15,30,31]. These basic science discoveries have led to numerous neural interface applications from brain-computer interfaces that extract brain signals from paralyzed patients and allow them to control robotic limbs and computer cursors to electrical stimulation technologies that restore sensory function or treat Parkinson's tremors [2,3,5,7-9,11,32,33]. The present short-communication takes a brief glance at the history of the field as well as a wide-angle perspective of the emerging challenges and opportunities on the horizon along the frontier of neural engineering.

\section{Brief History of Microscale Implantable Neural Technologies}

Microscale neural interfaces were originally developed as research tools for academic investigation into the neural mechanisms that regulate attention, movement, and behavior [12]. Classically, these microscale interfaces have fallen into three categories: (1) microwire arrays (Figure 1a), (2) microfabricated planar arrays (Figure 1b), and (3) micromachined arrays (Figure 1c).

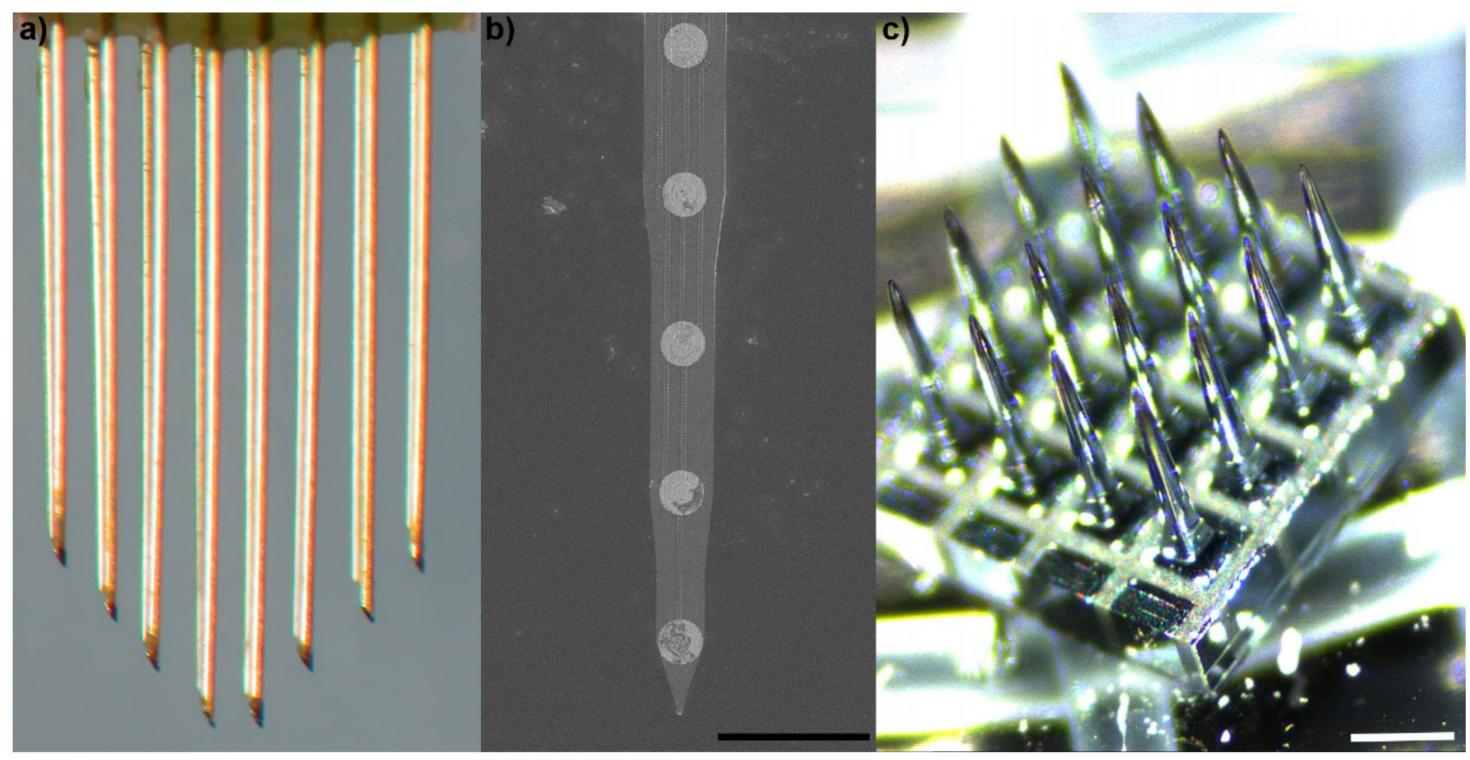

Figure 1. Classes of microscale implantable neural technologies: (a) $50 \mu \mathrm{m}$ polyimide-insulated tungsten microwire with chiseled tips (Tucker-Davis Technologies, Alachua, FL, USA); (b) microfabricated silicon Michigan array with iridium electrode sites (NeuroNexus Technologies, Ann Arbor, MI, USA), scale $=100 \mu \mathrm{m}$; (c) macromachined boron-doped silicon array (Blackrock Microsystems, Salt Lake City, UT, USA), each needle is electrically separated at the base with glass. Scale $=400 \mu \mathrm{m}$.

Microwire electrodes have two key components: (1) a conductive core wires, and (2) an insulator such as glass, parylene, teflon, or polyimide. Generally, the insulation is exposed at the recording site at the tip. Sometimes, other electrode site materials are deposited on the tip of the wire, before insulation or after removal of the insulation from the tip, in order to improve the electrical properties of the 
microelectrode. These wires are typically manually assembled into bed of needle arrays with several different strategies employed to align the wires [34].

Microfabricated planar arrays are typically engineered through photolithography of silicon, metals, and polymers [35]. These arrays are generally microfabricated through layering of multiple conductive and non-conductive materials leading to a planar configuration. While early planar arrays were made from rigid silicon (such as the Michigan arrays), flexible configurations have been developed, including planar arrays that can be rolled, folded, or stacked into 3D configurations [36].

Micromachined arrays are similar to microwire arrays. Instead of assembling individual wires into an array, a block of silicon is micromachined into a pillar of needles [37]. Band-saws are used to mill large blocks of conductive (boron-doped) silicon into individual pillars. During the milling process, non-conductive glass is used to hold the pillars in a bed of needle configuration. Once the square pillars are etched into round pillars, the electrode tip material and insulation are deposited onto the array in a manner similar to microwires. Due to the band-saw micromachining process, it is much more difficult to develop arrays that have staggered configurations when compared to microwire arrays. However, it is much easier to precisely align all of the needles to have the same angle.

These three array technologies form the basic classes of implantable microscale neural interfaces; however, the diversity within these classes has dramatically increased in both functionality and application (Figure 2). Advances in materials and biomaterials, microfabrication techniques, and packaging have enabled a large breadth of distinct configurations over a wide range of design space parameters [36,38-57]. Still, it is crucial to recognize that optimizing one key parameter often leads to trade-offs on other critical parameters, and failure to maintain the functional domain in each of the crucial parameter spaces will lead to a non-functional device [36]. For example, while flexible polymer devices are hypothesized to reduce tissue inflammation and improve the electrode-tissue interface, the materials and designs behind these compliant devices typically result in more brittle implants, increased resistance and lower signal conductivity, higher impedance, greater shunt leakage, and enhancement of motion related electromagnetic artifacts [36,58]. A comprehensive examination of technical advances and trade-offs in microscale technology design space parameters has been covered in a separate review [36]. While much of the technological development of neural interfaces has focused on improving electrically stimulating and recording from central nervous system (CNS) targets, some recent advances have fundamentally altered the traditional limits of neural implants.

For example, optogenetics has dramatically altered the functionality of what once were exclusively electrical neural interfaces. Optogenetics includes transgenically expressing photon-gated ion channels called opsins in neuronal and non-neuronal cells whose cell activity are dependent on ion concentration [59]. Today, optogenetics also includes transgenically expressing fluorescent indicators into cells where the intensity level of the indicator changes based on the activity of the cells [60]. This is typically carried out by creating chimera proteins with a fluorescent protein, such as green fluorescent protein. The chimera is created such that the fluorescent protein is slightly denatured at rest. The other half of the chimera protein is designed to bind to key molecules of interest, such as calcium (released during action potentials) or glutamate [61-63]. The binding of the effector molecule leads to a conformation change in the binding site in the chimera, which rearranges the fluorescent protein into a conformation that allows the protein to fluoresce brightly, compared to the denatured state at rest. The adoption of optogenetic technology in the neuroscience community has motivated incorporation of waveguides as well as light-emitting and sensing diodes into microscale neural interfaces [36,40]. 

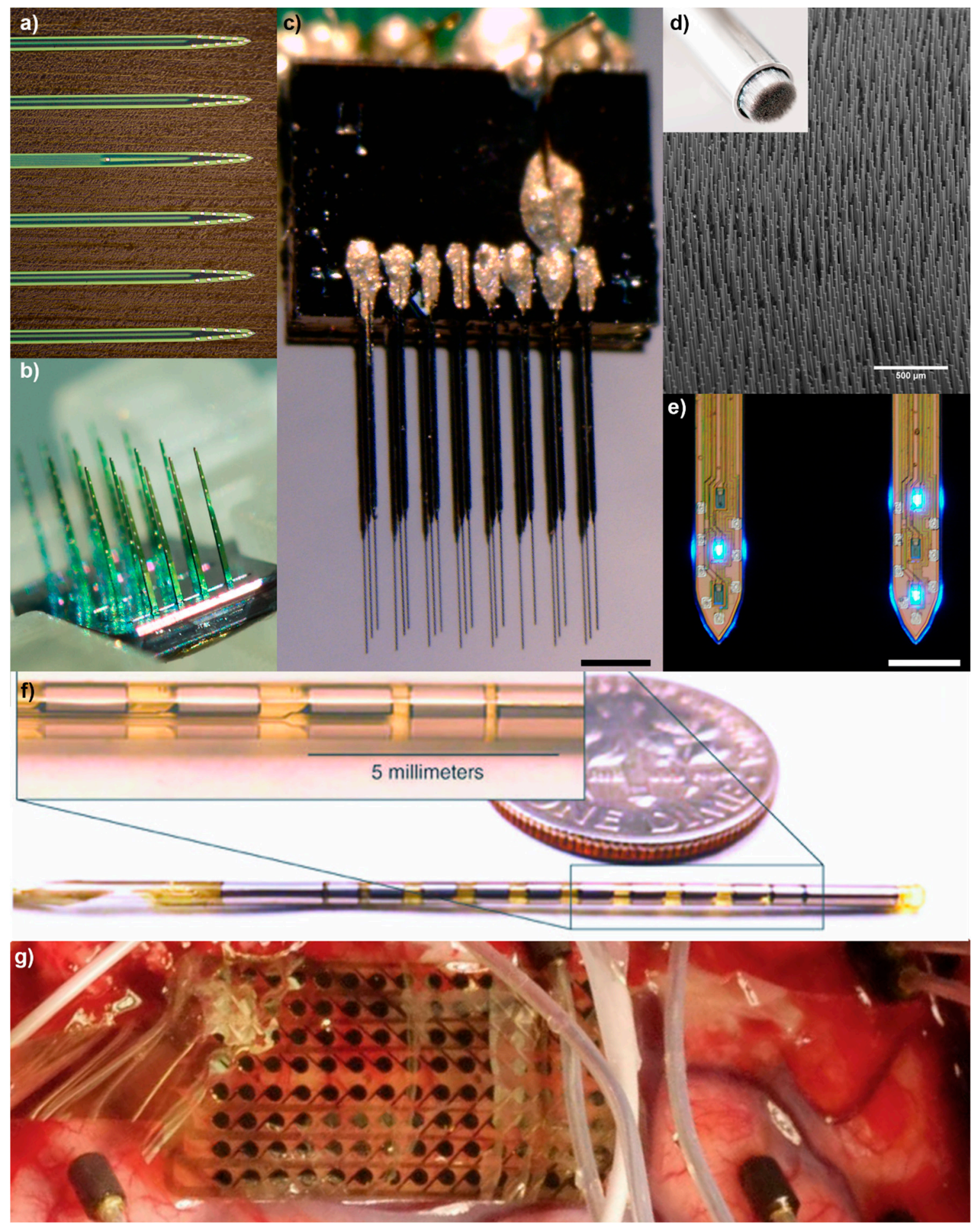

Figure 2. Advances in microscale neural interfaces: (a) 64-channel Buszaki Array (Neuronexus); (b) 128-channel Matrix Array (Neuronexus); (c) 24-channel ultra-small carbon fiber array on silicon stacks (courtesy of Paras Patel/Cynthia Chestek), scale $=100 \mu \mathrm{m}$; (d) high-density ultra-small microwire array (Paradromics Inc., San Jose, CA, USA), scale $=500 \mu \mathrm{m}$; (e) $\mu$ LED silicon optoelectrode (courtesy of NeuroNex MINT Hub at University of Michigan, Ann Arbor, MI, USA (http:/ / mint.engin.umich.edu)), scale $=100 \mu \mathrm{m}$; (f) a standard-sized $1.27 \mathrm{~mm}$ diameter Lawrence Livermore National Laboratories (LLNL) DBS-style penetrating probe constructed using microfabrication techniques, allowing for a higher-density of electrodes and avoiding typical hand-assembly techniques; and (g) A LNLL 128-channel microelectrocorticography $(\mu \mathrm{ECoG})$ array used for language mapping on awake patients. This $20-\mu \mathrm{m}$-thick flexible electrode array is constructed using thin-film polymers and metals and features $1.2 \mathrm{~mm}$ diameter electrodes. 
Similarly, a better understanding of the nervous system and foreign body response in the central nervous system has motivated the development of peripheral nerve interfaces. The central nervous system (CNS) is separated from the rest of the body by the blood-brain barrier (BBB). It was once believed that the brain was "immune privileged". Today, this is understood to be an inaccurate dogma [64,65]. However, the inflammatory response and immune response that are triggered during surgical implantation of brain neural interfaces, as well as the threat of serious consequences from brain tissue infection along percutaneous connectors, have led investigators to search for less invasive neural interface approaches [66,67]. In parallel, new discoveries about the autonomic nervous system have led to the validation that modulating activity of peripheral nerves that feed into the brain can cause systemic physiological changes [24,25]. While early proof-of-concept studies utilized brain neural interfaces or modified brain neural interface technologies, interfacing with peripheral nerves requires dramatic differences in structure and design criteria compared to brain neural interfaces that are more suited to recording signals from neuronal cell bodies rather than axons.

Advancements in genetic engineering, biophysics, and a better understanding of functional connectivity and anatomy has opened up novel modalities for interfacing with the nervous system. In addition, as basic science understanding of the nervous system increases, it becomes possible to identify new targets for interfacing with the body and different aspects of physiology. Each new nervous system target requires a custom design in order to optimally interface with the nerve or neuron. This is especially true when interfacing the same peripheral physiological target across different animal models or different ages of the same model. Furthermore, it may be necessary, depending on the target, to consider "personalized device designs" similar to personalized medicine which accounts for person-to-person variability in clinical applications.

\section{Challenges on the Horizon}

Despite these numerous success stories, many challenges, and as a result, great opportunities remain unexplored $[36,58,68]$. There remains large variability in performance even between identical devices [69] due to both biological [58,67,70-72] and material integrity variance [73-75], even within the same subject [71,72]. Nevertheless, the field of neural engineering has reached a tipping point due to pioneers in neuroscience, technology development, and neurosurgery. Although many of the foundational components are primed for commercial growth of neural interfaces, there are still constraints in neural technology translation due to the unpredictability of discovery science. In addition, it remains highly risky to build a business plan around basic science breakthroughs. Therefore, big pharmaceutical companies have only recently started to gain confidence in foundational neural engineering science in order to invest in neurotechnology development. It is important to recognize that the considerable work necessary to advance the frontiers of neural interface science and lay the foundation for neural engineering had to come from tax-payers, government organizations (e.g., United States Department of Veterans Affairs (VA), Department of Defense (DoD), National Institute of Health (NIH), National Science Foundation (NSF)), and donors, rather than businesses. This foundational academic research is an educational and cultural process that is necessary but difficult to evaluate in terms of technology development due to the long time-scales between basic science discovery and developing technology applications [76]. However, because of the long time-scales, it is crucial to advocate for investing today, especially in order to avoid losing the tremendous academic, government, and industry momentum that has built up in the neural engineering field.

\section{Need for the Science of Neural Engineering}

Neural engineering is at crucial point, in which, unlike other established engineering industries, the basic scientific knowledge foundational for neural engineering is disproportionately incomplete. This limited understanding of the human brain shrouds undiscovered opportunities for advancement in neurotechnology. Biology is perhaps the most complex regulatory system known, and within biology, the nervous system is perhaps the most sophisticated control system that exists. As such, it is 
not possible to overpower biology with rudimentary physics and engineering. Instead, development of microscale neural interfaces requires a more challenging titration of increasing information bandwidth while minimizing injury and inflammation of the host tissue. Therefore, it is critical to continue advancing both technology development and neurobiology in parallel.

Currently, the advancement of neuroscience is limited by the current capabilities of neurotechnology tools. Similarly, the development of devices is limited by the inadequate understanding of which designs and parameter trade-offs need to be optimized in order to maximize the extraction of meaningful neural signals [36]. Due to the long-time scales between basic science research and development of technology applications, the neural engineering field has long experienced deep criticisms on the shortage of clinical applications and aiding patients. Today, greater emphasis in neural engineering is placed on clinical impact over basic science research. However, in order to dramatically advance neural engineering, it is necessary to advance the science of neural engineering. In other words, it is necessary to continue to invest in the development of technology and studies that are designed to expand scientific knowledge rather than for therapeutic applications [22,46,58,74,77-96], even when the market segment is currently too small to support commercialization.

For example, the standard Blackrock arrays have $400 \mu \mathrm{m}$ shank pitch [97]. This is not because $400 \mu \mathrm{m}$ is the optimal pitch to maximize signal detection or the optimal pitch to record from neighboring cortical columns. Studies in the hippocampus CA1 of rats showed that acutely the maximum recording radius of an extracellular electrode was 80-160 $\mu \mathrm{m}$ [98]. The $400 \mu \mathrm{m}$ pitch was chosen because it was the width of the band-saw available at the time [37]. To this day, despite technological advancements that enable greater ranges of pitches, the physiologically optimal pitch for electrodes remains unknown. A major challenge for elucidating this optimal pitch is that it is necessary to evaluate a battery of different pitches individually. One might expect that a single design with a small pitch could easily allow oversampling to identify the optimal pitch for minimizing overlap. This would in theory identify the minimum pitch for enabling the densest recording configuration. However, the act of implanting the denser array leads to greater tissue strain, tissue response, and neurodegeneration, which ultimately alters the pattern of functional neurons around the implant $[36,94]$.

The level of tissue response is also not limited to pitch, but also depends on the footprint of the probe, shape of tine, and surface chemistry of the interface, making it difficult to translate findings from one design to another [96,99]. Furthermore, there is an additional layer of complexity that is added due to the fact that the tissue response is dynamic and as a result, the optimal pitch is expected to also be dynamic over time $[100,101]$. The basic science discovery of identifying the optimal pitch has long-range impact on technology development. However, brain injury, neurodegeneration, neural regeneration, limited translatability across device designs, and immediate clinical impact and innovation is deemed to be too limited for current peer-review processes and commercial research.

Similarly, a major focus of research surrounding implantable neural interfaces are on neurons, implantable devices, and scar tissue around implants. However, rapidly growing evidence point to vasculature and glia as important regulators of neuronal health, network activity, and brain health $[66,67,102-105]$. Unfortunately, basic science studies aimed at understanding how glia and vascular dysfunction contribute to neural interface failure remain as long-range investments for improving neural interfaces and do not have immediate commercial value. These are only a few examples of many important topics that are critical to the overall advancement of the field, such as packaging (hermetic sealing) and glial-vascular interface technologies (as opposed to neural interface technologies) [36,68].

\section{Need for Scientific and Engineering Convergence}

Neural interface engineering requires a confluence of basic science, applied science, and engineering. For example, each anatomical target in the brain has distinct structures and circuit 
organization. Different brain regions are also composed of different structures of vascular network and different glial cell types as well as different ratios of neurons to glial cells. Even within neuronal cell-types, different regions of the nervous system are composed of uniquely diverse combination of excitatory and inhibitory neurons. This means that answering specific basic neuroscience questions can require technology designed for a specific target brain region and optimized to answer the specific question at hand. In other words, long-standing unanswered scientific questions could be better addressed by custom designs instead of a one-size-fits-all design. Unfortunately, from a financial point of view, a design that can only be applied to one specific experimental paradigm has limited commercial value due to a small and restricted market segment. Therefore, it is necessary to support academic infrastructures to accommodate technology development specifically designed to answer basic science questions.

The first steps to achieving this goal is that the engineers need to understand the anatomy, physiology, unintended consequences or "side-effects" of their designs, and the scientific principle behind the question their technology intended to answer. Similarly, scientists need to understand the limitations of materials, microfabrication techniques, failure modalities "in the field", and design-driven technology development. Scientists need to guide technology development to optimally answer scientific questions without adding confounding variables to their study. Because functional microscale neural interfaces require fine titration of design parameters that are interdependent on each other [36], it is necessary for scientists to understand how achieving one optimal parameter can break functionality of other interdependent parameters. Therefore, engineering scientists and scientific engineers are both necessary in advancing the frontiers of the nervous system and integrating the newly found discoveries into technologies that interface directly or indirectly with the nervous system. For clinical applications, additional specialists are necessary including clinicians, patients, and caregivers or other "end-users" that interact with individuals who receive the neurotechnology.

The development of neurotechnologies requires a convergence of multiple disciplinary backgrounds including electrical engineering, electrochemistry, mechanical engineering, computer science, physics, biochemistry, biomechanics, material science, optics, biomaterials, packaging, ergonomics, molecular and cellular neurobiology, clinical science, and health care services. This requires both a wide breadth of expertise as well as enough cross-training depth to be able to integrate multiple engineering and scientific fields as well as end-user needs. While it is necessary to draw on multiple disciplines in the form of teams, the delays of the feedback loop between team members are limited by the speed in which team-members can communicate with each other. A commonly sought strategy to shorten that loop is to house multiple expertise in a single mind. However, this requires considerable cross-training time and effort on behalf of the individual. Given the growing scientific knowledge and accelerated advancement of engineering, it is becoming increasingly demanding for an individual to be fully proficient in all relevant scientific, engineering, and clinical expertise. Therefore, it is crucial for neural engineers to form teams of engineers, scientists, clinicians, and end-users as well as develop efficient communication techniques to reach the next level of technology development. While an increasing number of labs and programs strive to achieve this integration of science and engineering, this requires substantial contribution from individuals to learn, incorporate, and pass on training.

In turn, this means that the critical challenge for neural interface education and training is in converging neurobiology and neural engineering. Biology and engineering are often taught divergently with minimal overlap instead of being taught in an integrated and convergent manner. The nervous system is one of the most sophisticated computational systems, whose neural network activity is tightly regulated by the neural vascular unit and glia. Therefore, it stands to reason, as engineers, that by understanding the mechansims of how neurons, glia, and the neurovascular units regulate the neural network, it will be possible to identify new targets and means for interfacing with the nervous system in order to treat and repair diseases and injuries. However, in order to achieve this, it is necessary 
to bring together a diverse set of expertise, perspectives, and problem solving approaches, but have the capability to rapidly communicate with a common set of neuroscience and neural engineering "language".

\section{Need for Diversity}

While the ultimate goal of the BRAIN Initiative (NSF, NIH, etc.) and commercial Bioelectronic Medicine (Galvani Bioelectronics (GSK and Verily), NeuraLink, Kernel, etc.) is to understand brain function and treat neurological and physiological disease via the nervous system, the critical hurdle is placed on unreliable neuroelectronic interfaces over relevant time scales and the limited understanding in the neural interfacing field [36,67,68,97,106-109]. Just as a diversity of expertise is necessary to develop the next-generation microscale neural interfaces, it is necessary to have a diversity of perspectives and problem-solving approaches. The consequence of lack of diversity translates into limited diversity of opinion and perspectives, the blind spread of popular dogma, and the quenching of minority views. For example, a prevailing hypothesis in the field is that flexible devices will out preform traditional stiff implants. While plenty of evidence suggests that tissue injury is reduced around softer biomaterials, 50 years of polymer microelectrode research and limited success support the unpopular view that flexible polymer implants suffer from higher electrical impedance, higher resistivity, lower material strengths, higher shunt capacitance, larger device sizes, and new delamination issues that result in poorer performance compared to traditional devices [36,58]. This demonstrates issues in diversity as emphasized by NSF, "Diversity-of thought, perspective, and experience - is essential to achieving excellence in 21st century science and engineering research and education" [110]. Multi-disciplinary training in science and engineering are necessary, as well as diversity in perspective to understand the underlying problem and diversity in the approach of solving the problem. It is crucial to recognize that diversity in perspective and approach often stem from diversity in cultural and socio-economic backgrounds.

This diversity in approach to understanding the underlying problem and approach to problem-solving are deeply entangled with cultural and social backgrounds [111]. One study showed that gender diversity is correlated to $41 \%$ higher productivity compared to all-female or all-male teams [112]. Another study found that companies were 15\% more likely to gain financial returns for companies in the top quartile of gender diversity and 35\% more likely for companies in the top quartile for racial/ethnic diversity [113]. These studies add to a growing body of research that demonstrates gender, cultural, and ethnic diversity improves productivity, medical research, and clinical outcomes [114-170]. While similar studies in neural interface engineering have not been carried out, evidence in other fields suggest a potential for growth in the field by addressing gender and ethnic diversity. In a multi-disciplinary field such as microscale neural interface engineering, it is important for teams to have a diverse multi-disciplinary portfolio of ideas, skills, interests, technical background, and cultural and social backgrounds [111].

Therefore, it is crucial to protect and nurture researchers and prospective-researchers of underrepresented minorities who have been the victims of biases. In a seminal study by Rosenthal and Fode [171], half of wild-type littermates were randomly labeled "smart rats" and researchers were asked to compare the performance of these "smart rats" he "discovered" against the other half of the litter. What he showed was that the "smart rats" significantly out-performed their littermate clones in maze-tasks. He further described the Experimenter Expectancy Effect in which the experimenter's bias leads to unconscious behavioral cues that in turn influence the behavioral outcome of the subject. While the potential of these clones should be statistically identical, the "normal rat" group did not reach their potential due to the interactions with the experimenter. Therefore, in promoting diversity, it is crucial to recognize the metrics, which are measures of past performance, do not represent future potential, in individuals who grew up in environments of bias including women, non-binary gender minorities, and ethnic minorities [172]. This further extends to the fact that "equal opportunity" cannot equate "equal distribution" until such time that all implicit biases are eliminated [172]. Similarly, 
multiple studies have demonstrated that affirmative action admittees with lower incoming scores have a higher predisposition to success [173-175]. Therefore, it is necessary to provide for underrepresented minorities to counter the history of bias, facilitate reaching their full potential, and contribute to the diverse perspectives and problem-solving approaches necessary to address the multifaceted challenges surrounding neural interfaces.

\section{Conclusions}

Microscale neural interfaces have demonstrated great potential in basic neuroscience research and clinical neuroprosthetics. While these early results have generated enormous enthusiasm, limitations, and challenges in reliability and large performance variability remain. In other words, there is much more to be explored and discovered at the frontiers of microscale neural interfaces. Pioneers that are advancing these frontiers will be better positioned with cross-training in microfabrication/biomaterials engineering and neurobiology/neuroscience, as well as assembling teams with a diverse set of technical expertise as well as culture backgrounds. This is because fundamental basic science research is an academic and cultural process, and as greater cultural diversity is intermingled into this process, richer and deeper discoveries will be generated.

Funding: TDYK was financially supported by NIH National Institute of Neurological Disorders and Stroke (Grant R01NS062019, R01NS094396, R01NS089688, R21NS108098) and DARPA-BAA-16-09-NESD-FP-001.

Acknowledgments: The author would like to thank James R. Eles and Kip A. Ludwig for valuable input and discussion. In addition, the author would like to thank Victor Rush, Tucker-Davis Technologies, Rio Vetter, NeuroNexus, Rajmohan Bhandari, Sandeep Negi, Blackrock Microsystems, Paras R. Patel, Cynthia Chestek, Matthew Angle, Yifan Kong, Paradromic Inc., John Seymour, Euisik Yoon, NeuroNex MINT Hub, Razi-ul Haque, Shivshankar Sundaram, Lawrence Livermore National Laboratories, and Eddie Change at UCSF for devices or images of arrays.

Conflicts of Interest: The author declares no financial, political, or ethnic conflict of interest. Specifically, based on a reviewer's comment, the author points out that Asian men do not fall under the category of underrepresented minorities.

\section{References}

1. House, L.R. Cochlear implant: The beginning. Laryngoscope 1987, 97 Pt 1, 996-997.

2. House, W.F. Cochlear implants. Ann. Otol. Rhinol. Laryngol. 1976, 85 Pt 2 (Suppl. 27), 1-93. [CrossRef]

3. Dobelle, W.H.; Mladejovsky, M.G.; Girvin, J.P. Artifical vision for the blind: Electrical stimulation of visual cortex offers hope for a functional prosthesis. Science 1974, 183, 440-444. [CrossRef] [PubMed]

4. Dobelle, W.; Mladejovsky, M. Phosphenes produced by electrical stimulation of human occipital cortex, and their application to the development of a prosthesis for the blind. J. Physiol. 1974, 243, 553-576. [CrossRef] [PubMed]

5. Wodlinger, B.; Downey, J.E.; Tyler-Kabara, E.C.; Schwartz, A.B.; Boninger, M.L.; Collinger, J.L. Ten-dimensional anthropomorphic arm control in a human brain-machine interface: Difficulties, solutions, and limitations. J. Neural Eng. 2015, 12, 016011. [CrossRef] [PubMed]

6. Wang, W.; Collinger, J.L.; Degenhart, A.D.; Tyler-Kabara, E.C.; Schwartz, A.B.; Moran, D.W.; Weber, D.J.; Wodlinger, B.; Vinjamuri, R.K.; Ashmore, R.C.; et al. An electrocorticographic brain interface in an individual with tetraplegia. PLoS ONE 2013, 8, e55344. [CrossRef] [PubMed]

7. Collinger, J.L.; Wodlinger, B.; Downey, J.E.; Wang, W.; Tyler-Kabara, E.C.; Weber, D.J.; McMorland, A.J.; Velliste, M.; Boninger, M.L.; Schwartz, A.B. High-performance neuroprosthetic control by an individual with tetraplegia. Lancet 2013, 381, 557-564. [CrossRef]

8. Hochberg, L.R.; Bacher, D.; Jarosiewicz, B.; Masse, N.Y.; Simeral, J.D.; Vogel, J.; Haddadin, S.; Liu, J.; Cash, S.S.; van der Smagt, P.; et al. Reach and grasp by people with tetraplegia using a neurally controlled robotic arm. Nature 2012, 485, 372-375. [CrossRef] [PubMed]

9. Hochberg, L.R.; Serruya, M.D.; Friehs, G.M.; Mukand, J.A.; Saleh, M.; Caplan, A.H.; Branner, A.; Chen, D.; Penn, R.D.; Donoghue, J.P. Neuronal ensemble control of prosthetic devices by a human with tetraplegia. Nature 2006, 442, 164-171. [CrossRef] [PubMed] 
10. Cushing, H. A note upon the faradic stimulation of the postcentral gyrus in conscious patients. Brain 1909, 32, 44-53. [CrossRef]

11. Flesher, S.N.; Collinger, J.L.; Foldes, S.T.; Weiss, J.M.; Downey, J.E.; Tyler-Kabara, E.C.; Bensmaia, S.J.; Schwartz, A.B.; Boninger, M.L.; Gaunt, R.A. Intracortical microstimulation of human somatosensory cortex. Sci. Transl. Med. 2016, 8, 361ra141. [CrossRef] [PubMed]

12. Strumwasser, F. Long-term recording' from single neurons in brain of unrestrained mammals. Science 1958, 127, 469-470. [CrossRef] [PubMed]

13. Kipke, D.R.; Shain, W.; Buzsaki, G.; Fetz, E.; Henderson, J.M.; Hetke, J.F.; Schalk, G. Advanced neurotechnologies for chronic neural interfaces: New horizons and clinical opportunities. J. Neurosci. 2008, 28, 11830-11838. [CrossRef] [PubMed]

14. Schwartz, A.B.; Cui, X.T.; Weber, D.J.; Moran, D.W. Brain-controlled interfaces: Movement restoration with neural prosthetics. Neuron 2006, 52, 205-220. [CrossRef] [PubMed]

15. Giancoli, D.C. Physics: Principles with Applications; Prentice Hall: Upper Saddle River, NJ, USA, 1998.

16. Galvani, L.; Aldini, G. Aloysii Galvani... De Viribus Electricitatis in Motu Musculari Commentarius cum ioannis Aldini Dissertatione et notis. Accesserunt Epistolx ad Animalis Electricitatis Theoriam Pertinentes; Apud Societatem Typographicam: Paris, France, 1792.

17. Galvani, L. D Viribus Electricitatis in Motu Musculari: Commentarius; Bologna: Tip; Istituto delle Scienze: Bologna, Italy, 1791; p. 58.

18. Du Bois-Reymond, E.H. Untersuchungen über Thierische Elektricität. Anal. Phys. 1884, 151, $463-464$. [CrossRef]

19. Fritsch, G.; Hitzig, E. Ueber die elektrische Erregbarkeit des Grosshirns. Arch. Anat. Physiol. Wiss. Medizin. 1870, 37, 300-332.

20. Volta, A. XVII. On the electricity excited by the mere contact of conducting substances of different kinds. In a letter from Mr. Alexander Volta, FRS Professor of Natural Philosophy in the University of Pavia, to the Rt. Hon. Sir Joseph Banks, Bart. KBPR S. Philos. Trans. R. Soc. Lond. 1800, 90, 403-431. [CrossRef]

21. Dow, B.M.; Vautin, R.G.; Bauer, R. The mapping of visual space onto foveal striate cortex in the macaque monkey. J. Neurosci. 1985, 5, 890-902. [CrossRef] [PubMed]

22. Iordanova, B.; Vazquez, A.L.; Kozai, T.D.Y.; Fukuda, M.; Kim, S.G. Optogenetic investigation of the variable neurovascular coupling along the interhemispheric circuits. J. Cereb. Blood Flow Metab. 2018, 38, 627-640. [CrossRef] [PubMed]

23. Stecker, M. Factors Affecting Stimulus Artifact: Solution Factors. EC Neurol. 2017, 5, 52-61.

24. Ben-Menachem, E. Vagus-nerve stimulation for the treatment of epilepsy. Lancet Neurol. 2002, 1, 477-482. [CrossRef]

25. Kahn, A. Motion artifacts and streaming potentials in relation to biological electrodes. In Proceedings of the Dig 6th International Conference Medical Electronics and Biological Engineering, Tokyo, Japan, 22-27 August 1965; Volume 112, pp. 562-563.

26. Espinosa, J.; Aiello, M.T.; Naritoku, D.K. Revision and removal of stimulating electrodes following long-term therapy with the vagus nerve stimulator. Surg. Neurol. 1999, 51, 659-664. [CrossRef]

27. Penry, J.K.; Dean, J.C. Prevention of intractable partial seizures by intermittent vagal stimulation in humans: Preliminary results. Epilepsia 1990, 31 (Suppl. 2), S40-S43. [CrossRef]

28. Rutecki, P. Anatomical, physiological, and theoretical basis for the antiepileptic effect of vagus nerve stimulation. Epilepsia 1990, 31 (Suppl. 2), S1-S6. [CrossRef]

29. Brindley, G.S.; Lewin, W.S. The sensations produced by electrical stimulation of the visual cortex. J. Physiol. 1968, 196, 479-493. [CrossRef] [PubMed]

30. Schwartz, A.B. Cortical neural prosthetics. Annu. Rev. Neurosci. 2004, 27, 487-507. [CrossRef] [PubMed]

31. Paralikar, K.; Rao, C.; Clement, R.S. Automated reduction of non-neuronal signals from intra-cortical microwire array recordings by use of correlation technique. In Proceedings of the 30th Annual International Conference of the IEEE EMBS 2008 Engineering in Medicine and Biology Society, Vancouver, BC, Canada, 21-24 August 2008; pp. 46-49.

32. Agnesi, F.; Muralidharan, A.; Baker, K.B.; Vitek, J.L.; Johnson, M.D. Fidelity of frequency and phase entrainment of circuit-level spike activity during DBS. J. Neurophysiol. 2015, 114, 825-834. [CrossRef] [PubMed] 
33. Collinger, J.L.; Kryger, M.A.; Barbara, R.; Betler, T.; Bowsher, K.; Brown, E.H.; Clanton, S.T.; Degenhart, A.D.; Foldes, S.T.; Gaunt, R.A.; et al. Collaborative approach in the development of high-performance brain-computer interfaces for a neuroprosthetic arm: Translation from animal models to human control. Clin. Transl. Sci. 2014, 7, 52-59. [CrossRef] [PubMed]

34. Schmidt, E.; McIntosh, J.; Bak, M. Long-term implants of Parylene-C coated microelectrodes. Med. Biol. Eng. Comput. 1988, 26, 96-101. [CrossRef] [PubMed]

35. Drake, K.L.; Wise, K.D.; Farraye, J.; Anderson, D.J.; BeMent, S.L. Performance of planar multisite microprobes in recording extracellular single-unit intracortical activity. IEEE Trans. Biomed. Eng. 1988, 35, 719-732. [CrossRef] [PubMed]

36. Wellman, S.M.; Eles, J.R.; Ludwig, K.A.; Seymour, J.P.; Michelson, N.J.; McFadden, W.E.; Vazquez, A.L.; Kozai, T.D. A Materials Roadmap to Functional Neural Interface Design. Adv. Funct. Mater. 2018, 28, 201701269. [CrossRef] [PubMed]

37. Campbell, P.K.; Jones, K.E.; Huber, R.J.; Horch, K.W.; Normann, R.A. A silicon-based, three-dimensional neural interface: Manufacturing processes for an intracortical electrode array. IEEE Trans. Biomed. Eng. 1991, 38, 758-768. [CrossRef] [PubMed]

38. Patel, P.R.; Zhang, H.; Robbins, M.T.; Nofar, J.B.; Marshall, S.P.; Kobylarek, M.J.; Kozai, T.D.Y.; Kotov, N.A.; Chestek, C.A. Chronic In Vivo Stability Assessment of Carbon Fiber Microelectrode Arrays. J. Neural Eng. 2016, 13, 066002. [CrossRef] [PubMed]

39. Patel, P.R.; Na, K.; Zhang, H.; Kozai, T.D.Y.; Kotov, N.A.; Yoon, E.; Chestek, C.A. Insertion of linear $8.4 \mathrm{mu}$ $\mathrm{m}$ diameter 16 channel carbon fiber electrode arrays for single unit recordings. J. Neural Eng. 2015, 12. [CrossRef] [PubMed]

40. Mendrela, A.E.; Kim, K.; English, D.; McKenzie, S.; Seymour, J.P.; Buzsáki, G.; Yoon, E. A High-Resolution Opto-Electrophysiology System With a Miniature Integrated Headstage. IEEE Trans. Biomed. Circuits Syst. 2018. [CrossRef] [PubMed]

41. Seymour, J.P.; Wu, F.; Wise, K.D.; Yoon, E. State-of-the-art MEMS and microsystem tools for brain research. Microsyst. Nanoeng. 2017, 3, 16066. [CrossRef]

42. Kampasi, K.; Stark, E.; Seymour, J.; Na, K.; Winful, H.G.; Buzsáki, G.; Wise, K.D.; Yoon, E. Fiberless multicolor neural optoelectrode for in vivo circuit analysis. Sci. Rep. 2016, 6, 30961. [CrossRef] [PubMed]

43. Seymour, E.Ç.; Freedman, D.S.; Gökkavas, M.; Özbay, E.; Sahin, M.; Ünlü, M.S. Improved selectivity from a wavelength addressable device for wireless stimulation of neural tissue. Front. Neuroeng. 2014, 7, 5. [CrossRef] [PubMed]

44. Khurram, A.; Seymour, J.P. Investigation of the photoelectrochemical effect in optoelectrodes and potential uses for implantable electrode characterization. In Proceedings of the 2013 35th Annual International Conference of the IEEE Engineering in Medicine and Biology Society (EMBC), Osaka, Japan, 3-7 July 2013; pp. 3032-3035.

45. Seymour, J.P.; Langhals, N.B.; Anderson, D.J.; Kipke, D.R. Novel multi-sided, microelectrode arrays for implantable neural applications. Biomed. Microdevices 2011. [CrossRef] [PubMed]

46. Eles, J.R.; Vazquez, A.L.; Snyder, N.R.; Lagenaur, C.F.; Murphy, M.C.; Kozai, T.D.Y.; Cui, X.T. Neuroadhesive L1 coating attenuates acute microglial attachment to neural electrodes as revealed by live two-photon microscopy. Biomaterials 2017, 113, 279-292. [CrossRef] [PubMed]

47. Du, Z.J.; Kolarcik, C.L.; Kozai, T.D.Y.; Luebben, S.D.; Sapp, S.A.; Zheng, X.S.; Nabity, J.A.; Cui, X.T. Ultrasoft microwire neural electrodes improve chronic tissue integration. Acta Biomater. 2017. [CrossRef] [PubMed]

48. Khilwani, R.; Gilgunn, P.J.; Kozai, T.D.Y.; Ong, X.C.; Korkmaz, E.; Gunalan, P.K.; Cui, X.T.; Fedder, G.K.; Ozdoganlar, O.B. Ultra-miniature ultra-compliant neural probes with dissolvable delivery needles: Design, fabrication and characterization. Biomed. Microdevices 2016, 18, 97. [CrossRef] [PubMed]

49. Kozai, T.D.Y.; Catt, K.; Du, Z.; Na, K.; Srivannavit, O.; Haque, R.-U.M.; Seymour, J.; Wise, K.D.; Yoon, E.; Cui, X.T. Chronic In Vivo Evaluation of PEDOT/CNT for Stable Neural Recordings. IEEE Trans. Bio-Med. Eng. 2016, 63, 111-119. [CrossRef] [PubMed]

50. Kolarcik, C.L.; Luebben, S.D.; Sapp, S.A.; Hanner, J.; Snyder, N.; Kozai, T.D.Y.; Chang, E.; Nabity, J.A.; Nabity, S.T.; Lagenaur, C.F.; et al. Elastomeric and soft conducting microwires for implantable neural interfaces. Soft Matter 2015, 11, 4847-4861. [CrossRef] [PubMed]

51. Alba, N.A.; Du, Z.J.; Catt, K.A.; Kozai, T.D.Y.; Cui, X.T. In vivo electrochemical analysis of a PEDOT/MWCNT neural electrode coating. Biosensors 2015, 5, 618-646. [CrossRef] [PubMed] 
52. Kolarcik, C.L.; Catt, K.; Rost, E.; Albrecht, I.N.; Bourbeau, D.; Du, Z.; Kozai, T.D.Y.; Luo, X.; Weber, D.J.; Cui, X.T. Evaluation of poly(3,4-ethylenedioxythiophene)/carbon nanotube neural electrode coatings for stimulation in the dorsal root ganglion. J. Neural Eng. 2015, 12, 016008. [CrossRef] [PubMed]

53. Kozai, T.D.Y.; Alba, N.A.; Zhang, H.; Kotov, N.A.; Gaunt, R.A.; Cui, X.T. Nanostructured Coatings for Improved Charge Delivery to Neurons. In Nanotechnology and Neuroscience: Nano-electronic, Photonic and Mechanical Neuronal Interfacing; De Vittorio, M., Martiradonna, L., Assad, J., Eds.; Springer: New York, NY, USA, 2014; pp. 71-134.

54. Gilgunn, P.J.K.R.; Kozai, T.D.Y.; Weber, D.J.; Cui, X.T.; Erdos, G.; Ozdoganlar, O.B.; Fedder, G.K. An ultra-compliant, scalable neural probes with molded biodissolvable delivery vehicle. In Proceedings of the 2012 IEEE 25th International Conference on Micro Electro Mechanical Systems (MEMS), Paris, France, 29 January-2 Febuary 2012; Volume 2012, pp. 56-59.

55. Kozai, T.D.Y.; Kipke, D.R. Insertion shuttle with carboxyl terminated self-assembled monolayer coatings for implanting flexible polymer neural probes in the brain. J. Neurosci. Methods 2009, 184, 199-205. [CrossRef] [PubMed]

56. Escamilla-Mackert, T.; Langhals, N.B.; Kozai, T.D.Y.; Kipke, D.R. Insertion of a three dimensional silicon microelectrode assembly through a thick meningeal membrane. Conf. Proc. IEEE Eng. Med. Biol. Soc. 2009, 2009, 1616-1618. [PubMed]

57. Kozai, T.D.Y.; Jaquins-gerstl, A.S.; Vazquez, A.L.; Michael, A.C.; Cui, X.T. Dexamethasone retrodialysis attenuates microglial response to implanted probes in vivo. Biomaterials 2016, 87, 157-169. [CrossRef] [PubMed]

58. Michelson, N.J.; Vazquez, A.L.; Eles, J.R.; Salatino, J.W.; Purcell, E.K.; Williams, J.J.; Cui, X.T.; Kozai, T.D.Y. Multi-scale, multi-modal analysis uncovers complex relationship at the brain tissue-implant neural interface: New Emphasis on the Biological Interface. J. Neural Eng. 2018, 15. [CrossRef] [PubMed]

59. Boyden, E.S.; Zhang, F.; Bamberg, E.; Nagel, G.; Deisseroth, K. Millisecond-timescale, genetically targeted optical control of neural activity. Nat. Neurosci. 2005, 8, 1263. [CrossRef] [PubMed]

60. Tian, L.; Hires, S.A.; Mao, T.; Huber, D.; Chiappe, M.E.; Chalasani, S.H.; Petreanu, L.; Akerboom, J.; McKinney, S.A.; Schreiter, E.R.; et al. Imaging neural activity in worms, flies and mice with improved GCaMP calcium indicators. Nat. Methods 2009, 6, 875-881. [CrossRef] [PubMed]

61. Dana, H.; Chen, T.W.; Hu, A.; Shields, B.C.; Guo, C.; Looger, L.L.; Kim, D.S.; Svoboda, K. Thy1-GCaMP6 transgenic mice for neuronal population imaging in vivo. PLoS ONE 2014, 9, e108697. [CrossRef] [PubMed]

62. Chen, Q.; Cichon, J.; Wang, W.; Qiu, L.; Lee, S.-J.; Campbell, N.R.; DeStefino, N.; Goard, M.J.; Fu, Z.; Yasuda, R.; et al. Imaging Neural Activity Using Thy1-GCaMP Transgenic Mice. Neuron 2012, 76, 297-308. [CrossRef] [PubMed]

63. Xie, Y.; Chan, A.W.; McGirr, A.; Xue, S.; Xiao, D.; Zeng, H.; Murphy, T.H. Resolution of high-frequency mesoscale intracortical maps using the genetically encoded glutamate sensor iGluSnFR. J. Neurosci. 2016, 36, 1261-1272. [CrossRef] [PubMed]

64. Louveau, A.; Harris, T.H.; Kipnis, J. Revisiting the mechanisms of CNS immune privilege. Trends Immunol. 2015, 36, 569-577. [CrossRef] [PubMed]

65. Carson, M.J.; Doose, J.M.; Melchior, B.; Schmid, C.D.; Ploix, C.C. CNS immune privilege: Hiding in plain sight. Immunol. Rev. 2006, 213, 48-65. [CrossRef] [PubMed]

66. Wellman, S.M.; Kozai, T.D.Y. Understanding the Inflammatory Tissue Reaction to Brain Implants to Improve Neurochemical Sensing Performance. ACS Chem. Neurosci. 2017. [CrossRef] [PubMed]

67. Kozai, T.D.Y.; Jaquins-Gerstl, A.; Vazquez, A.L.; Michael, A.C.; Cui, X.T. Brain Tissue Responses to Neural Implants Impact Signal Sensitivity and Intervention Strategies. ACS Chem. Neurosci. 2015, 6, 48-67. [CrossRef] [PubMed]

68. Salatino, J.W.; Ludwig, K.A.; Kozai, T.D.Y.; Purcell, E.K. Glial responses to implanted electrodes in the brain. Nat. BME 2017, 1, 862-877. [CrossRef]

69. Williams, J.C.; Rennaker, R.L.; Kipke, D.R. Long-term neural recording characteristics of wire microelectrode arrays implanted in cerebral cortex. Brain Res. Brain Res. Protoc. 1999, 4, 303-313. [CrossRef]

70. Bedell, H.W.; Hermann, J.K.; Ravikumar, M.; Lin, S.; Rein, A.; Li, X.; Molinich, E.; Smith, P.D.; Selkirk, S.M.; Miller, R.H.; et al. Targeting CD14 on blood derived cells improves intracortical microelectrode performance. Biomaterials 2018, 163, 163-173. [CrossRef] [PubMed] 
71. Rousche, P.J.; Normann, R.A. Chronic recording capability of the Utah Intracortical Electrode Array in cat sensory cortex. J. Neurosci. Methods 1998, 82, 1-15. [CrossRef]

72. Kozai, T.D.Y.; Marzullo, T.C.; Hooi, F.; Langhals, N.B.; Majewska, A.K.; Brown, E.B.; Kipke, D.R. Reduction of neurovascular damage resulting from microelectrode insertion into the cerebral cortex using in vivo two-photon mapping. J. Neural Eng. 2010, 7, 046011. [CrossRef] [PubMed]

73. Kozai, T.D.Y.; Catt, K.; Li, X.; Gugel, Z.V.; Olafsson, V.T.; Vazquez, A.L.; Cui, X.T. Mechanical failure modes of chronically implanted planar silicon-based neural probes for laminar recording. Biomaterials 2015, 37, $25-39$. [CrossRef] [PubMed]

74. Prasad, A.; Xue, Q.S.; Dieme, R.; Sankar, V.; Mayrand, R.C.; Nishida, T.; Streit, W.J.; Sanchez, J.C. Abiotic-biotic characterization of $\mathrm{Pt} / \mathrm{Ir}$ microelectrode arrays in chronic implants. Front. Neuroeng. 2014, 7, 2. [CrossRef] [PubMed]

75. Barrese, J.C.; Rao, N.; Paroo, K.; Triebwasser, C.; Vargas-Irwin, C.; Franquemont, L.; Donoghue, J.P. Failure mode analysis of silicon-based intracortical microelectrode arrays in non-human primates. J. Neural Eng. 2013, 10, 066014. [CrossRef] [PubMed]

76. Wilson, R.R. Congress' Joint Committee on Atomic Energy. In Authorizing Legislation for FY 1970; Congress of the United States: Washington, DC, USA, 1969.

77. Michelson, N.J.; Islam, R.; Vazquez, A.L.; Ludwig, K.A.; Kozai, T.D.Y. Calcium activation of frequency dependent temporally phasic, localized, and dense population of cortical neurons by continuous electrical stimulation. BioRxiv 2018. [CrossRef]

78. Michelson, N.J.; Kozai, T.D.Y. Isoflurane and Ketamine Differentially Influence Spontaneous and Evoked Laminar Electrophysiology in Mouse V1. J. Neurophysiol. 2018. [CrossRef] [PubMed]

79. Wellman, S.M.; Kozai, T.D.Y. In vivo spatiotemporal dynamics of NG2 glia activity caused by neural electrode implantation. Biomaterials 2018, 164, 121-133. [CrossRef] [PubMed]

80. Eles, J.; Vazquez, A.; Kozai, T.; Cui, X. In vivo imaging of neuronal calcium during electrode implantation: Spatial and temporal mapping of damage and recovery. Biomaterials 2018. [CrossRef] [PubMed]

81. Kozai, T.D.Y.; Eles, J.R.; Vazquez, A.L.; Cui, X.T. Two-photon imaging of chronically implanted neural electrodes: Sealing methods and new insights. J. Neurosci. Methods 2016, 256, 46-55. [CrossRef] [PubMed]

82. Kozai, T.D.Y.; Du, Z.; Gugel, Z.V.; Smith, M.A.; Chase, S.M.; Bodily, L.M.; Caparosa, E.M.; Friedlander, R.M.; Cui, X.T. Comprehensive chronic laminar single-unit, multi-unit, and local field potential recording performance with planar single shank electrode arrays. J. Neurosci. Methods 2015, 242, 15-40. [CrossRef] [PubMed]

83. Kozai, T.D.Y.; Li, X.; Bodily, L.M.; Caparosa, E.M.; Zenonos, G.A.; Carlisle, D.L.; Friedlander, R.M.; Cui, X.T. Effects of caspase-1 knockout on chronic neural recording quality and longevity: Insight into cellular and molecular mechanisms of the reactive tissue response. Biomaterials 2014, 35, 9620-9634. [CrossRef] [PubMed]

84. Kozai, T.D.Y.; Vazquez, A.L.; Weaver, C.L.; Kim, S.-G.; Cui, X.T. In vivo two-photon microscopy reveals immediate microglial reaction to implantation of microelectrode through extension of processes. J. Neural Eng. 2012, 9, 066001-066001. [CrossRef] [PubMed]

85. Golabchi, A.; Wu, B.; Li, X.; Carlisle, D.L.; Kozai, T.D.Y.; Friedlander, R.M.; Cui, X.T. Melatonin improves quality and longevity of chronic neural recording. Biomaterials 2018, 180, 225-239. [CrossRef] [PubMed]

86. Prasad, A.; Xue, Q.-S.; Sankar, V.; Nishida, T.; Shaw, G.; Streit, W.J.; Sanchez, J.C. Comprehensive characterization and failure modes of tungsten microwire arrays in chronic neural implants. J. Neural Eng. 2012, 9, 056015. [CrossRef] [PubMed]

87. Hermann, J.K.; Ravikumar, M.; Shoffstall, A.; Ereifej, E.S.; Kovach, K.; Chang, J.; Soffer, A.; Wong, C.T.; Srivastava, V.; Smith, P.; et al. Inhibition of the cluster of differentiation 14 innate immunity pathway with IAXO-101 improves chronic microelectrode performance. J. Neural Eng. 2017. [CrossRef] [PubMed]

88. Ravikumar, M.; Sunil, S.; Black, J.; Barkauskas, D.S.; Haung, A.Y.; Miller, R.H.; Selkirk, S.M.; Capadona, J.R. The roles of blood-derived macrophages and resident microglia in the neuroinflammatory response to implanted intracortical microelectrodes. Biomaterials 2014, 35, 8049-8064. [CrossRef] [PubMed]

89. Nolta, N.F.; Christensen, M.B.; Crane, P.D.; Skousen, J.L.; Tresco, P.A. BBB leakage, astrogliosis, and tissue loss correlate with silicon microelectrode array recording performance. Biomaterials 2015, 53, 753-762. [CrossRef] [PubMed] 
90. Biran, R.; Martin, D.C.; Tresco, P.A. The brain tissue response to implanted silicon microelectrode arrays is increased when the device is tethered to the skull. J. Biomed. Mater. Res. A 2007, 82, 169-178. [CrossRef] [PubMed]

91. Saxena, T.; Karumbaiah, L.; Gaupp, E.A.; Patkar, R.; Patil, K.; Betancur, M.; Stanley, G.B.; Bellamkonda, R.V. The impact of chronic blood-brain barrier breach on intracortical electrode function. Biomaterials 2013. [CrossRef] [PubMed]

92. Karumbaiah, L.; Saxena, T.; Carlson, D.; Patil, K.; Patkar, R.; Gaupp, E.A.; Betancur, M.; Stanley, G.B.; Carin, L.; Bellamkonda, R.V. Relationship between intracortical electrode design and chronic recording function. Biomaterials 2013, 34, 8061-8074. [CrossRef] [PubMed]

93. Karumbaiah, L.; Norman, S.E.; Rajan, N.B.; Anand, S.; Saxena, T.; Betancur, M.; Patkar, R.; Bellamkonda, R.V. The upregulation of specific interleukin (IL) receptor antagonists and paradoxical enhancement of neuronal apoptosis due to electrode induced strain and brain micromotion. Biomaterials 2012, 33, 5983-5996. [CrossRef] [PubMed]

94. McConnell, G.C.; Rees, H.D.; Levey, A.I.; Gutekunst, C.A.; Gross, R.E.; Bellamkonda, R.V. Implanted neural electrodes cause chronic, local inflammation that is correlated with local neurodegeneration. J. Neural Eng. 2009, 6, 56003. [CrossRef] [PubMed]

95. Purcell, E.K.; Seymour, J.P.; Yandamuri, S.; Kipke, D.R. In vivo evaluation of a neural stem cell-seeded prosthesis. J. Neural Eng. 2009, 6, 026005. [CrossRef] [PubMed]

96. Seymour, J.P.; Kipke, D.R. Neural probe design for reduced tissue encapsulation in CNS. Biomaterials 2007, 28, 3594-3607. [CrossRef] [PubMed]

97. Cody, P.A.; Eles, J.R.; Lagenaur, C.F.; Kozai, T.D.; Cui, X.T. Unique electrophysiological and impedance signatures between encapsulation types: An analysis of biological Utah array failure and benefit of a biomimetic coating in a rat model. Biomaterials 2018, 161, 117-128. [CrossRef] [PubMed]

98. Henze, D.A.; Borhegyi, Z.; Csicsvari, J.; Mamiya, A.; Harris, K.D.; Buzsaki, G. Intracellular features predicted by extracellular recordings in the hippocampus in vivo. J. Neurophysiol. 2000, 84, 390-400. [CrossRef] [PubMed]

99. Kozai, T.D.Y.; Langhals, N.B.; Patel, P.R.; Deng, X.; Zhang, H.; Smith, K.L.; Lahann, J.; Kotov, N.A.; Kipke, D.R. Ultrasmall implantable composite microelectrodes with bioactive surfaces for chronic neural interfaces. Nat. Mater. 2012, 11, 1065-1073. [CrossRef] [PubMed]

100. Kozai, T.D.Y.; Gugel, Z.; Li, X.; Gilgunn, P.J.; Khilwani, R.; Ozdoganlar, O.B.; Fedder, G.K.; Weber, D.J.; Cui, X.T. Chronic tissue response to carboxymethyl cellulose based dissolvable insertion needle for ultra-small neural probes. Biomaterials 2014, 35, 9255-9268. [CrossRef] [PubMed]

101. Potter, K.A.; Buck, A.C.; Self, W.K.; Capadona, J.R. Stab injury and device implantation within the brain results in inversely multiphasic neuroinflammatory and neurodegenerative responses. J. Neural Eng. 2012, 9, 046020. [CrossRef] [PubMed]

102. Montagne, A.; Nikolakopoulou, A.M.; Zhao, Z.; Sagare, A.P.; Si, G.; Lazic, D.; Barnes, S.R.; Daianu, M.; Ramanathan, A.; Go, A. Pericyte degeneration causes white matter dysfunction in the mouse central nervous system. Nat. Med. 2018, 24, 326. [CrossRef] [PubMed]

103. Wang, F.; Yang, Y.-J.; Yang, N.; Chen, X.-J.; Huang, N.-X.; Zhang, J.; Wu, Y.; Liu, Z.; Gao, X.; Li, T. Enhancing Oligodendrocyte Myelination Rescues Synaptic Loss and Improves Functional Recovery after Chronic Hypoxia. Neuron 2018. [CrossRef] [PubMed]

104. Gorelick, P.B.; Scuteri, A.; Black, S.E.; DeCarli, C.; Greenberg, S.M.; Iadecola, C.; Launer, L.J.; Laurent, S.; Lopez, O.L.; Nyenhuis, D. Vascular contributions to cognitive impairment and dementia: A statement for healthcare professionals from the American Heart Association/American Stroke Association. Stroke 2011, 42, 2672-2713. [CrossRef] [PubMed]

105. Wellman, S.M.; Cambi, F.; Kozai, T.D.Y. The role of oligodendrocytes and their progenitors on neural interface technology: A novel perspective on tissue regeneration and repair. Biomaterials 2018. [CrossRef] [PubMed]

106. Ward, M.P.; Rajdev, P.; Ellison, C.; Irazoqui, P.P. Toward a comparison of microelectrodes for acute and chronic recordings. Brain Res. 2009, 1282, 183-200. [CrossRef] [PubMed]

107. Tresco, P.A.; Winslow, B.D. The challenge of integrating devices into the central nervous system. Crit. Rev. Biomed. Eng. 2011, 39, 29-44. [CrossRef] [PubMed]

108. Liu, X.; McCreery, D.B.; Bullara, L.A.; Agnew, W.F. Evaluation of the stability of intracortical microelectrode arrays. IEEE Trans. Neural Syst. Rehabil. Eng. 2006, 14, 91-100. [CrossRef] [PubMed] 
109. Liu, X.; McCreery, D.B.; Carter, R.R.; Bullara, L.A.; Yuen, T.G.; Agnew, W.F. Stability of the interface between neural tissue and chronically implanted intracortical microelectrodes. IEEE Trans. Rehabil. Eng. 1999, 7,315-326. [PubMed]

110. Córdova, F.A. Dear Colleague Letter: NSF INCLUDES (Inclusion across the Nation of Communities of Learners of Underrepresented Discoverers in Engineering and Science); National Science Foundation: Alexandria, VA, USA, 2016.

111. Orfield, G. Diversity Challenged: Evidence on the Impact of Affirmative Action; ERIC: New York, NY, USA, 2001.

112. Ellison, S.F.; Mullin, W.P. Diversity, social goods provision, and performance in the firm. J. Econ. Manag. Strategy 2014, 23, 465-481. [CrossRef]

113. Hunt, V.; Layton, D.; Prince, S. Diversity Matters; McKinsey \& Company: New York, NY, USA, 2015.

114. Cox, T.H.; Lobel, S.A.; McLeod, P.L. Effects of ethnic group cultural differences on cooperative and competitive behavior on a group task. Acad. Manag. J. 1991, 34, 827-847.

115. Miller, T.; del Carmen Triana, M. Demographic diversity in the boardroom: Mediators of the board diversity-firm performance relationship. J. Manag. Stud. 2009, 46, 755-786. [CrossRef]

116. Richard, O.C.; Murthi, B.S.; Ismail, K. The impact of racial diversity on intermediate and long-term performance: The moderating role of environmental context. Strateg. Manag. J. 2007, 28, 1213-1233. [CrossRef]

117. Buttner, E.H.; Lowe, K.B.; Billings-Harris, L. The challenge of increasing minority-group professional representation in the United States: Intriguing findings. Int. J. Hum. Resour. Manag. 2009, 20, 771-789. [CrossRef]

118. Athey, S.; Avery, C.; Zemsky, P. Mentoring and diversity. Am. Econ. Rev. 2000, 90, 765-786. [CrossRef]

119. Hong, L.; Page, S.E. Groups of diverse problem solvers can outperform groups of high-ability problem solvers. Proc. Natl. Acad. Sci. USA 2004, 101, 16385-16389. [CrossRef] [PubMed]

120. Hoffman, L.R.; Maier, N.R. Quality and acceptance of problem solutions by members of homogeneous and heterogeneous groups. J. Abnorm. Soc. Psychol. 1961, 62, 401. [CrossRef] [PubMed]

121. McLeod, P.L.; Lobel, S.A.; Cox, T.H., Jr. Ethnic diversity and creativity in small groups. Small Group Res. 1996, 27, 248-264. [CrossRef]

122. Herring, C. Does diversity pay: Race, gender, and the business case for diversity. Am. Sociol. Rev. 2009, 74, 208-224. [CrossRef]

123. Grossman, G.M.; Maggi, G. Diversity and trade. Am. Econ. Rev. 2000, 90, 1255-1275. [CrossRef]

124. Jones, J.R.; Wilson, D.C.; Jones, P. Toward Achieving the "Beloved Community" in the Workplace: Lessons for Applied Business Research and Practice From the Teachings of Martin Luther King Jr. Bus. Soc. 2008, 47, 457-483. [CrossRef]

125. Watson, W.E.; Kumar, K.; Michaelsen, L.K. Cultural diversity's impact on interaction process and performance: Comparing homogeneous and diverse task groups. Acad. Manag. J. 1993, 36, 590-602.

126. Ostrom, E. The Difference: How the Power of Diversity Creates Better Groups, Firms, Schools, and Societies. By Page Scott E. Princeton: Princeton University Press, 2007. 448p. \$27.95 cloth, \$19.95 paper. Perspect. Politics 2008, 6, 828-829. [CrossRef]

127. Bristow, L.R.; Butler, A.S.; Smedley, B.D. In the Nation's Compelling Interest: Ensuring Diversity in the Health-Care Workforce; National Academies Press: Washington, DC, USA, 2004.

128. Antonio, A.L.; Chang, M.J.; Hakuta, K.; Kenny, D.A.; Levin, S.; Milem, J.F. Effects of racial diversity on complex thinking in college students. Psychol. Sci. 2004, 15, 507-510. [CrossRef] [PubMed]

129. Ruhe, J.; Eatman, J. Effects of racial composition on small work groups. Small Group Behav. 1977, 8, 479-486. [CrossRef]

130. Watson, W.E.; Kumar, K. Differences in decision making regarding risk taking: A comparison of culturally diverse and culturally homogeneous task groups. Int. J. Int. Relat. 1992, 16, 53-65. [CrossRef]

131. Copeland, L. Valuing Diversity, Part 1: Making the Most of Cultural Differences at the Workplace. Personnel $1988,65,52-54$.

132. Cox, T., Jr. Creating the Multicultural Organization: A Strategy for Capturing the Power of Diversity; Jossey-Bass: San Francisco, CA, USA, 2001.

133. Cox, T., Jr. The multicultural organization. Acad. Manag. Perspect. 1991, 5, 34-47. [CrossRef]

134. Cox, T.H.; Blake, S. Managing cultural diversity: Implications for organizational competitiveness. Acad. Manag. Perspect. 1991, 5, 45-56. [CrossRef] 
135. Maznevski, M.L. Understanding our differences: Performance in decision-making groups with diverse members. Hum. Relat. 1994, 47, 531-552. [CrossRef]

136. Mohammed, S.; Angell, L.C. Surface-and deep-level diversity in workgroups: Examining the moderating effects of team orientation and team process on relationship conflict. J. Organ. Behav. 2004, 25, 1015-1039. [CrossRef]

137. Richard, O.; McMillan, A.; Chadwick, K.; Dwyer, S. Employing an innovation strategy in racially diverse workforces: Effects on firm performance. Group Organ. Manag. 2003, 28, 107-126. [CrossRef]

138. Thomas, D.A. Diversity as strategy. Harv. Bus. Rev. 2004, 82, 98-98. [PubMed]

139. Johnson, N.L. Science of CI: Resources for change. In Collective Intelligence: Creating a Prosperous World at Peace; CreateSpace Independent Publishing Platform: Scotts Valley, CA, USA, 2008; pp. 265-274.

140. Johnson, N.L.; Watkins, J.H. The Where-How of Leadership Emergence (WHOLE) Landscape: Charting Emergent Collective Leadership. 2009. Available online: https://papers.ssrn.com/sol3/papers.cfm? abstract_id=1516618 (accessed on 26 Aug 2018).

141. Whitla, D.K.; Orfield, G.; Silen, W.; Teperow, C.; Howard, C.; Reede, J. Educational benefits of diversity in medical school: A survey of students. Acad. Med. 2003, 78, 460-466. [CrossRef] [PubMed]

142. Lakhan, S.E. Diversification of US medical schools via affirmative action implementation. BMC Med. Educ. 2003, 3, 6. [CrossRef] [PubMed]

143. Reichert, W.M. A Success Story: Recruiting \& Retaining Underrepresented Minority Doctoral Students in Biomedical Engineering. Lib. Educ. 2006, 92, 52-55.

144. Rabinowitz, H.K.; Diamond, J.J.; Veloski, J.J.; Gayle, J.A. The impact of multiple predictors on generalist physicians' care of underserved populations. Am. J. Public Health 2000, 90, 1225. [PubMed]

145. Saha, S.; Taggart, S.H.; Komaromy, M.; Bindman, A.B. Do patients choose physicians of their own race? Health Aff. 2000, 19, 76-83. [CrossRef] [PubMed]

146. Traylor, A.H.; Schmittdiel, J.A.; Uratsu, C.S.; Mangione, C.M.; Subramanian, U. Adherence to cardiovascular disease medications: Does patient-provider race/ethnicity and language concordance matter? J. Gen. Intern. Med. 2010, 25, 1172-1177. [CrossRef] [PubMed]

147. Noah, B.A. The participation of underrepresented minorities in clinical research. Am. J. Law Med. 2003, 29, 221. [PubMed]

148. Saha, S.; Shipman, S.A. Race-neutral versus race-conscious workforce policy to improve access to care. Health Aff. 2008, 27, 234-245. [CrossRef] [PubMed]

149. Kim, M.J.; Holm, K.; Gerard, P.; McElmurry, B.; Foreman, M.; Poslusny, S.; Dallas, C. Bridges to the doctorate: Mentored transition to successful completion of doctoral study for underrepresented minorities in nursing science. Nurs. Outlook 2009, 57, 166-171. [CrossRef] [PubMed]

150. Magnus, S.A.; Mick, S.S. Medical schools, affirmative action, and the neglected role of social class. Am. J. Public Health 2000, 90, 1197. [PubMed]

151. Shaya, F.T.; Gbarayor, C.M. The case for cultural competence in health professions education. Am. J. Pharm. Educ. 2006, 70, 124. [CrossRef] [PubMed]

152. Komaromy, M.; Grumbach, K.; Drake, M.; Vranizan, K.; Lurie, N.; Keane, D.; Bindman, A.B. The role of black and Hispanic physicians in providing health care for underserved populations. N. Engl. J. Med. 1996, 334, 1305-1310. [CrossRef] [PubMed]

153. Guiton, G.; Chang, M.J.; Wilkerson, L. Student body diversity: Relationship to medical students' experiences and attitudes. Acad. Med. 2007, 82, S85-S88. [CrossRef] [PubMed]

154. Mitchell, D.A.; Lassiter, S.L. Addressing health care disparities and increasing workforce diversity: The next step for the dental, medical, and public health professions. Am. J. Public Health 2006, 96, 2093-2097. [CrossRef] [PubMed]

155. Stoddard, J.J.; Back, M.R.; Brotherton, S.E. The respective racial and ethnic diversity of US pediatricians and American children. Pediatrics 2000, 105, 27-31. [CrossRef] [PubMed]

156. Okunseri, C.; Bajorunaite, R.; Abena, A.; Self, K.; Iacopino, A.M.; Flores, G. Racial/ethnic disparities in the acceptance of Medicaid patients in dental practices. J. Public Health Dent. 2008, 68, 149-153. [CrossRef] [PubMed]

157. Friedemann, M.-L.; Pagan-Coss, H.; Mayorga, C. The workings of a multicultural research team. J. Transcult. Nurs. 2008, 19, 266-273. [CrossRef] [PubMed] 
158. Ginther, D.K.; Schaffer, W.T.; Schnell, J.; Masimore, B.; Liu, F.; Haak, L.L.; Kington, R.S. Diversity in Academic Biomedicine: An Evaluation of Education and Career Outcomes with Implications for Policy. 2009. Available online: https:/ / core.ac.uk/download/pdf/6268557.pdf (accessed on 26 Aug 2018).

159. Brown, T.T.; Scheffler, R.M.; Tom, S.E.; Schulman, K.A. Does the Market Value Racial and Ethnic Concordance in Physician-Patient Relationships? Health Serv. Res. 2007, 42, 706-726. [CrossRef] [PubMed]

160. Teal, C.R.; Street, R.L. Critical elements of culturally competent communication in the medical encounter: A review and model. Soc. Sci. Med. 2009, 68, 533-543. [CrossRef] [PubMed]

161. Grumbach, K.; Coffman, J.M.; Young, J.Q.; Vranizan, K.; Blick, N. Physician supply and medical education in California. A comparison with national trends. West. J. Med. 1998, 168, 412. [PubMed]

162. Katz, R.V.; Kegeles, S.S.; Kressin, N.R.; Green, B.L.; James, S.A.; Wang, M.Q.; Russell, S.L.; Claudio, C. Awareness of the Tuskegee Syphilis Study and the US presidential apology and their influence on minority participation in biomedical research. Am. J. Public Health 2008, 98, 1137-1142. [CrossRef] [PubMed]

163. Philips, B.; Mahan, J.; Perry, R. Minority recruitment to the health professions: A matched comparison six-year follow-up. J. Med. Educ. 1981, 56, 742-747. [CrossRef] [PubMed]

164. Thomson, W.A.; Ferry, P.G.; King, J.E.; Martinez-Wedig, C.; Michael, L.H. Increasing access to medical education for students from medically underserved communities: One program's success. Acad. Med. 2003, 78, 454-459. [CrossRef] [PubMed]

165. Saha, S.; Guiton, G.; Wimmers, P.F.; Wilkerson, L. Student body racial and ethnic composition and diversity-related outcomes in US medical schools. JAMA 2008, 300, 1135-1145. [CrossRef] [PubMed]

166. Daley, S.; Wingard, D.L.; Reznik, V. Improving the retention of underrepresented minority faculty in academic medicine. J. Natl. Med. Assoc. 2006, 98, 1435. [PubMed]

167. Thom, D.H.; Tirado, M.D.; Woon, T.L.; McBride, M.R. Development and evaluation of a cultural competency training curriculum. BMC Med. Educ. 2006, 6, 38. [CrossRef] [PubMed]

168. Pohlhaus, J.R.; Jiang, H.; Wagner, R.M.; Schaffer, W.T.; Pinn, V.W. Sex differences in application, success, and funding rates for NIH extramural programs. Acad. Med. 2011, 86, 759. [CrossRef] [PubMed]

169. Tabak, L.A.; Collins, F.S. Weaving a richer tapestry in biomedical science. Science 2011, 333, $940-941$. [CrossRef] [PubMed]

170. Heggeness, M.L.; Evans, L.; Pohlhaus, J.R.; Mills, S.L. Measuring diversity of the National Institutes of Health-funded workforce. Acad. Med. 2016, 91, 1164. [CrossRef] [PubMed]

171. Rosenthal, R.; Fode, K.L. The effect of experimenter bias on the performance of the albino rat. Syst. Res. Behav. Sci. 1963, 8, 183-189. [CrossRef]

172. Sowell, T. Affirmative Action around the World: An Empirical Study; Yale University Press: New Haven, CT, USA, 2004.

173. Massey, D.S.; Mooney, M. The effects of America's three affirmative action programs on academic performance. Soc. Prob. 2007, 54, 99-117. [CrossRef]

174. Sander, R.H. A systemic analysis of affirmative action in American law schools. Stan. Law Rev. 2004, $57,367$.

175. Holzer, H.; Neumark, D. Assessing affirmative action. J. Econ. Lit. 2000, 38, 483-568. [CrossRef]

(C) 2018 by the author. Licensee MDPI, Basel, Switzerland. This article is an open access article distributed under the terms and conditions of the Creative Commons Attribution (CC BY) license (http:// creativecommons.org/licenses/by/4.0/). 